\title{
E-government and E-services in Local Government: a Case Study
}

\author{
BAYONA-ORE, Sussy \\ Dirección de Investigación \\ Universidad Autónoma del Perú \\ Autopista Panamericana Sur Km 16.3, Villa El Salvador \\ Lima, PERÚ
}

MORALES LOZADA, Vicente

Universidad Técnica de Ambato

Av. Los Chasquis y Río Payamino, 180103

Ambato, ECUADOR

\begin{abstract}
E-government requires the intensive use of ICTs (information and communication technologies) in public institutions to deliver services to citizens efficiently and effectively. E-government allows the transformation of the citizen service delivery system, and its implementation is conditioned by a set of critical factors. The city halls are directly connected with citizens and deliver e-services, but the importance of this level of government is sometimes underestimated. This study aims to explore the influence of critical factors on the eservices implementation in city halls. The authors used a model to assess the e-government development index of 10 city halls and to know the provision of e-services of city halls. The results reveal that the city halls in the study currently offer e-services at the levels of presence and urban information. It important that the efforts of city halls must be oriented to the levels of interaction, transaction and e-democracy.
\end{abstract}

Keywords: E-government, Maturity level, E-services, Local government, ICT, Citizen

Received: February 3, 2021. Revised: June 13, 2021. Accepted: July 1, 2021. Published: July 9, 2021.

\section{Introduction}

The intensive use of ICTs (information and communication technologies) has enabled the emergence of different concepts such as egovernment, digital government or digital transformation (DT). All of these terms are related to the associated value for a public or private organisation that ICTs provide.

In particular, public organisations make intensive use of ICTs to deliver services efficiently and effectively. ICTs are associated with flexibility. modernity, efficiency, innovation and quality in service delivery [1]. E-government, meanwhile, is associated with transparency, participation and efficient service provision.

ICTs in public entities transform governments' operations, interactions with different actors in society and provision of services [2]. In the last decade a government strategy has been e-government [3]. Implementing e-government in an optimal way brings benefits to myriad stakeholders [4].

However, the unprecedented COVID-19 pandemic, which has forced social distancing and quarantine measures to reduce infections, has tested the e-government visions, tools and applications [5].

Despite the ability of local governments to directly connect with citizens and thus to provide services effectively [6], the importance of this level of government is sometimes overlooked or underestimated.

Analysing these services, several studies maintain that local governments remain in the early stages of e-government maturity [5], [7]. As local governments make efforts to adopt ICTs and deliver e-services to citizens, a number of critical success factors must be taken into account to obtain better results and improve the level of e-government development.

The factors required for successful implementation can be categorized as follows: (1) individual factors, including awareness, training and skills [4], [8], (2) organisational factors, including support from senior management, culture and finances [9], (3) technological factors, including ICT infrastructure and security [9] and (4) political 
factors, including leadership, the legal framework and administrative reform [10].

Also driving the implementation of e-government are the regulatory frameworks that various countries have implemented worldwide. One such framework involves public transparency, requiring public agencies to ensure their actions are observable by citizens.

We present a case study in which apply the egovernment model [11] to understand how the city halls delivery e-services to citizens, and what is the e-government index achieved. It focuses on the eservices delivered through the portal web of 10 city halls.

Also, identify the factors that should be considered to improve the e-services offered by local governments. The results allow researchers, practitioners or ICT leaders of city halls to know the index of e-government and the critical factors in initiatives to improve e-services.

\section{Background}

This section includes the concepts related to egovernment, e-services and critical success factors.

\subsection{E-government}

Different conceptual definitions for e-government have been advanced. Analysing these definitions, however, reveals several common words: ICT use, internet, services, citizen, effectiveness and efficiency, among others.

Naser et al. [12] envisions the advance of egovernment centered on the implementation of national policies, national plans, project development, state modernisation, public transparency and access to information.

Recognising that ICT improves the transparency of government management to minimise corruption, facilitates citizen participation, and improves management through e-services, the United Nations [13] identifies e-government among the sustainable development objectives necessary to support the implementation of Agenda 2030.

Through e-government, communication is facilitated from the government to the citizen and vice versa [9] to promote public transparency. Egovernment has been a strategy of state modernisation and administrative reform [14], and implies the government's use of ICTs to provide public services [15], [16].

\subsection{Critical success factors}

The extant literature and theoretical analyses describe and categorise the factors that influence egovernment into the technological, organisational, individual, institutional, and legal contexts [4], [8], [11], [17]. These factors must be considered by organisations [18].

Political leaders must demonstrate commitment, make decisions and take actions to promote the effective implementation of e-government [19] and leadership with an effective management process is also crucial [20]. The OECD [14] highlights support at the highest level as an essential criterion for the success of any reform.

The factors of leadership and commitment at the highest level are considered institutional factors [21]. Several authors [9], [22] have considered the visionary and strategic factors that ensure the success of e-government projects from their inception onwards.

In a previous study [17] a total of 11 critical factors were identified such as ICT infrastructure, security, support from top management, culture, finance or economy, strategy, training, awareness, political commitment, leadership, and legal framework.

\subsection{E-services}

Three characteristics define the e-services such as public, electronic (digital), and intangible [23]. and can be conceptualised as a gatekeeper to public services [24].

It is not easy to determine a precise definition of e-services [25], which can range from information from the city hall to forms to be filled out to more complicated systems.

E-services are frequently presented via institutional web portals where citizens can complete forms to register for access to services, engage in two-way communication with city hall and participate in government (e-democracy). Web portals are used for delivering information to all citizens.

\section{Methodology}

This research employs a case study design to answer its main question:

How do the critical factors impact the implementation of e-government in town halls?

Ten district town halls located in Lima comprise the sample. The unit of study is the web portal of the 
town hall to be evaluated to determine the egovernment index.

The national government, regional government and municipal government are part of the state structure. The municipal level of government includes the provincial town halls and the district town halls. The district town halls are the governing bodies closest to the citizen.

The district town halls maintain institutional web portals, which function as a means of bringing the town hall closer to the citizens. Through web portals, town halls offer e-services to citizens.

With the recent impact of COVID-19, offering citizens access to the town hall via web portals has become a way to reduce the number of face-to-face visits to the town hall. Of course, this function requires that the town halls have implemented the eservices required by their citizens.

Despite the efforts made by town halls, not all have managed to offer online services. The case study design allows us to explore variables for future statistical testing [26].

A method applied in the Latin American context, was used to evaluate the town halls [11]. It establishes the main e-services to be evaluated as well as the ideal values for each of the e-service levels. The e-services proposal integrates the eservices identified in the literature review and the eservices of the top 10 cities in the world ranking.

The following steps were followed to evaluate each of the e-services:

(1) identification of the web portal of each town hall

(2) analysis of the e-services each town hall offered, which involved assigning a score of ' 0 ' when the town hall did not provide the eservice and ' 1 ' when it did provide it

(3) evaluation of the e-services by stages of development using the weighting criteria for each of the e-government levels

(4) calculation of the town hall e-government development index.

Weighting criteria were determined for each of the e-government levels. The values were 0.25 at the presence level, 0.50 at the urban information level, 0.75 at the interaction level, 1.0 at the transaction level and 1.25 at the e-democracy level.

To calculate the e-government development index (e-value), the procedure suggested by Bayona and Morales [27] was used. The Equation (1) was used to calculate e-value, and the maximum e-value is 1 or $100 \%$.

$$
\begin{aligned}
& \text { e-value }=12 \times 0.25+7 \times 0.50+8 \times 0.75+9 \times 1+4 \times 1.25 \\
& \text { e-value } \%=26.5 / 26.5=1
\end{aligned}
$$

\section{Results}

The websites of 10 town halls were identified. Table 1 shows the results of the evaluation of the websites of the selected town halls, following the steps described in the methodology section.

Table 1. E-government development indices by stages and town halls

\begin{tabular}{llllllllllll}
\hline \multirow{2}{*}{ Level } & \multirow{2}{*}{ VMP* } & \multicolumn{1}{c}{ E-government development index } & \multicolumn{1}{c}{ Town halls M1-M10) } \\
\cline { 3 - 11 } & & M1 & M2 & M3 & M4 & M5 & M6 & M7 & M8 & M9 & M10 \\
\hline 1 & 3 & 0.50 & 0.83 & 0.67 & 0.75 & 0.50 & 0.92 & 0.67 & 0.67 & 0.92 & 0.83 \\
2 & 3.5 & 0.43 & 0.43 & 0.14 & 0.43 & 0.43 & 0.57 & 0.71 & 0.57 & 0.43 & 0.14 \\
3 & 6 & 0.25 & 0.88 & 0.50 & 0.38 & 0.38 & 0.75 & 0.38 & 0.50 & 0.50 & 0.63 \\
4 & 9 & 0.44 & 0.78 & 0.00 & 0.44 & 0.11 & 0.11 & 0.22 & 0.11 & 0.33 & 0.00 \\
5 & 5 & 0.00 & 0.00 & 0.00 & 0.00 & 0.00 & 0.00 & 0.00 & 0.00 & 0.00 & 0.00 \\
\hline Valour & 26.5 & 8.50 & 16.3 & 5.75 & 9.75 & 5.75 & 10.3 & 8.5 & 7.75 & 10 & 6.5 \\
\hline e_value (\%) & 1 & 0.31 & 0.61 & 0.22 & 0.37 & 0.22 & 0.39 & 0.32 & 0.29 & 0.38 & 0.25 \\
\hline *VMP: Maximum weighted value. & & & & & & & &
\end{tabular}

The values of the e-government index by level and the e-government index of the town hall also appear in Table 1. The results show that the vast majority of the city halls are at low levels of maturity. These results coincide with studies [5] [7] that state that local governments remain in the early stages of egovernment maturity.

Figure 1 shows the ranking according to the level of e-government development of the town halls selected. The results reveal that the vast majority of town halls, impelled by a regulatory framework that 
requires town halls to make their activities transparent through their web portals, have reached the presence level of maturity.

Only one town hall has reached an index higher than 0.5 (M1), while the rest of the town halls have an index lower than 0.4. At the presence level, some municipalities have not implemented the e-service search, and 50\% do not offer a web map or publish their hours of operation. At the urban information level, only $50 \%$ of the municipalities offer the city map e-service, and only $20 \%$ provide tourist information.

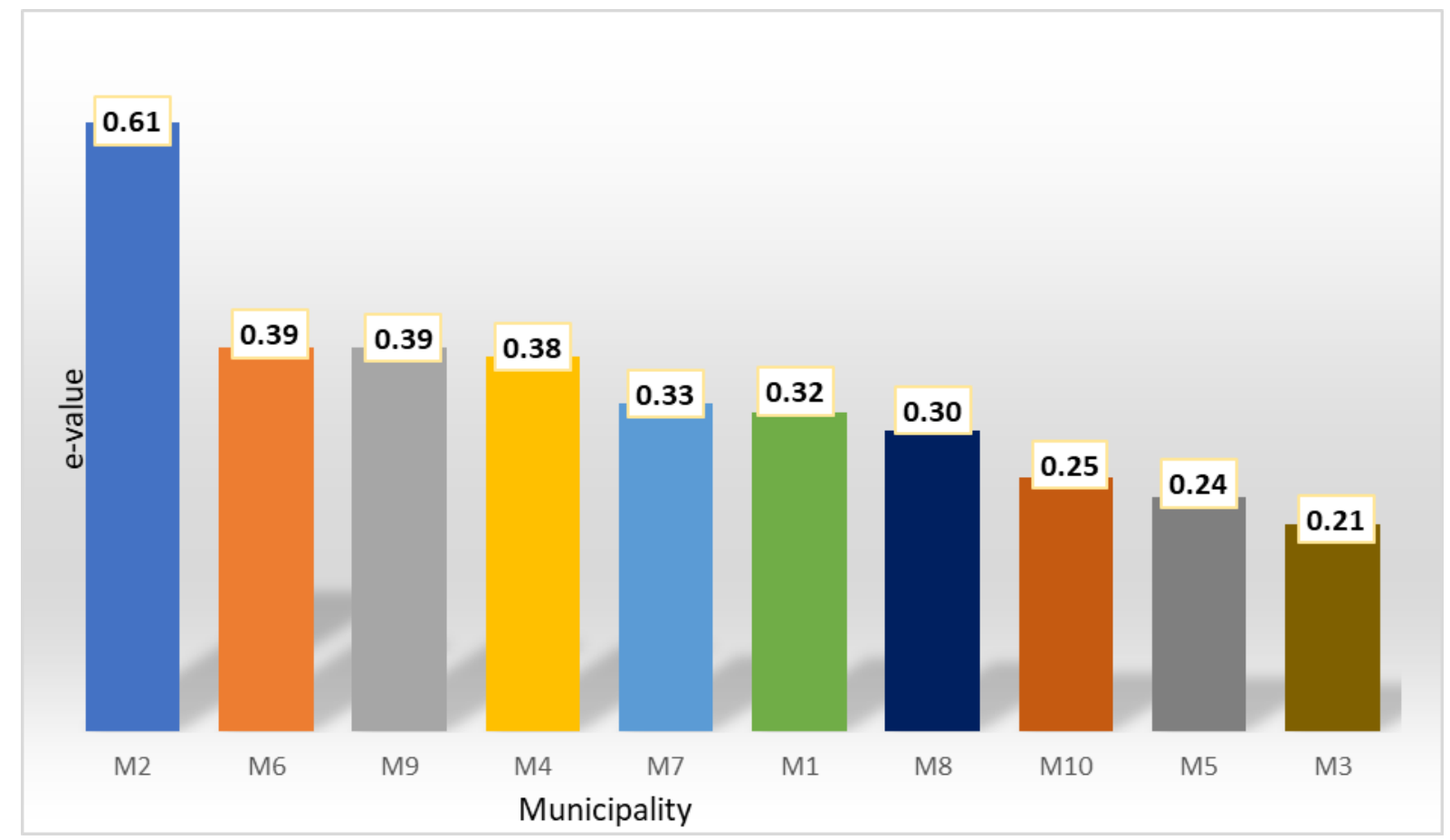

Figure 1. E-government ranking of town halls

At the level of interaction, the use of email should be increased as a means of communication providing a timely response. Likewise, the web portals are currently offered only in Spanish. At the transaction level, online payments are an option; however, it is necessary to implement online systems. At the level of e-democracy, finally, progress is extremely limited.

Additional progress requires that the digital government leader establish strategies to improve the web portals with citizen-oriented e-services with the top management support. Truly transformational leaders, moreover, must develop and inspire their subordinates to take responsibility for and commit themselves to challenging goals, intellectual stimulation and individualised considerations.

\subsection{Critical success factors}

Based on the above results, an analysis of the factors critical to the success of e-government initiatives was performed.

Figure 2 presents the interrelationships between these critical factors, levels of e-government and the e-services town halls provide. There are critical factors that influence on the implementation of eservices in city halls [17]. The list of e-services that are evaluated through the organisational web portals [7] are distributed in five levels such as presence, urban information, interaction, transaction, and edemocracy. The e-government index depends on the e-services implemented by the city halls. Table 2 describes the critical factors by e-government level.

The current situation of the town halls in this study reveals several factors that should be considered to improve the e-services offered to citizens.

All of the town halls have institutional web portals. Likewise, they are in the early stages of eservices maturity, i.e. at the presence and urban information levels, which entail maintaining a web portal and offering e-services oriented to the dissemination of the town halls' information.

Advancing towards the transaction level would require the town halls to establish basic infrastructure to support e-services, train their personnel and ensure 
the commitment of senior management, among other factors.

The commitment and support of the top management are particularly important factors that can improve e-government indices by making government actors aware of the advantages of egovernment for citizens. Compliance with the regulatory framework is also essential to make information transparent.

Table 2. E-government levels and critical factors for e-government

\begin{tabular}{|c|c|}
\hline Level & Critical factors \\
\hline Presence & $\begin{array}{l}\text { E-services, which provide online information without entailing any major relationship with } \\
\text { citizens, include basic search tools for downloading forms and files. At this stage, the institution } \\
\text { must have an ICT infrastructure that allows it to put services online. The DT leader, together with } \\
\text { senior management, must define the current and future ICT needs so that acquisitions can meet } \\
\text { those needs within the ICT governance framework. }\end{array}$ \\
\hline $\begin{array}{l}\text { Urban } \\
\text { information }\end{array}$ & $\begin{array}{l}\text { At this level, e-services provide information about urban transportation maps and city streets. This } \\
\text { information sometimes requires technological tools, such as GIS, or the possibility of a quick } \\
\text { search. Political commitment and support from senior management is needed to improve e- } \\
\text { government levels. The town hall must have adequate ICT staff to generate new services. These } \\
\text { personnel should be trained in the proper implementation of technological tools. Awareness and } \\
\text { sensitisation on the importance of e-government and its advantages for citizens, as well as an } \\
\text { overall culture oriented toward citizen service, should be created. Leadership of the administrative } \\
\text { staff must remain close to and in contact with citizens. }\end{array}$ \\
\hline Interaction & $\begin{array}{l}\text { E-services at this level entail simple communication-via email or telephone-between citizens } \\
\text { and the town hall. Complaints or grievances can be filed, appointments can be scheduled or } \\
\text { downloadable forms can be used for pre-filling. This level requires staff to manage } \\
\text { communications through forms and social networks. Moreover, it requires staff not only to } \\
\text { maintain an email address but also to provide citizens with timely responses. }\end{array}$ \\
\hline Transaction & $\begin{array}{l}\text { This level of e-services includes services that support bidirectional communication between the } \\
\text { town hall and citizens, such as authentication, request processing, etc. It allows the initiation, } \\
\text { follow-up and conclusion of any online procedure. At this level, resources must be adequate to } \\
\text { support the ICT infrastructure and put services online. In addition, training programmes must be } \\
\text { developed for ICT personnel. E-services at the transaction level should be interconnected with } \\
\text { public agencies to eliminate the need to duplicate information that already exists in those agencies' } \\
\text { databases. Because trust and security have been identified as limiting factors for the adoption of } \\
\text { ICT, security and cybersecurity must also be considered, and digital certificates should be } \\
\text { implemented. Finally, e-services at the transaction level should be accessible using mobile } \\
\text { devices. }\end{array}$ \\
\hline E-democracy & $\begin{array}{l}\text { E-services at the level of e-democracy include services, such as blogs, chats, forums, online } \\
\text { surveys, live transmissions, etc., that facilitate citizen participation on town hall issues. At this } \\
\text { stage, basic infrastructure is required to make the town hall more accessible via live transmission } \\
\text { of municipal council sessions and public consultations. Adequate human resources are also } \\
\text { required to manage these e-services. Citizen access to the internet is another aspect to be } \\
\text { considered. Finally, a culture promoting citizen participation must underlie this level of e-services. }\end{array}$ \\
\hline
\end{tabular}




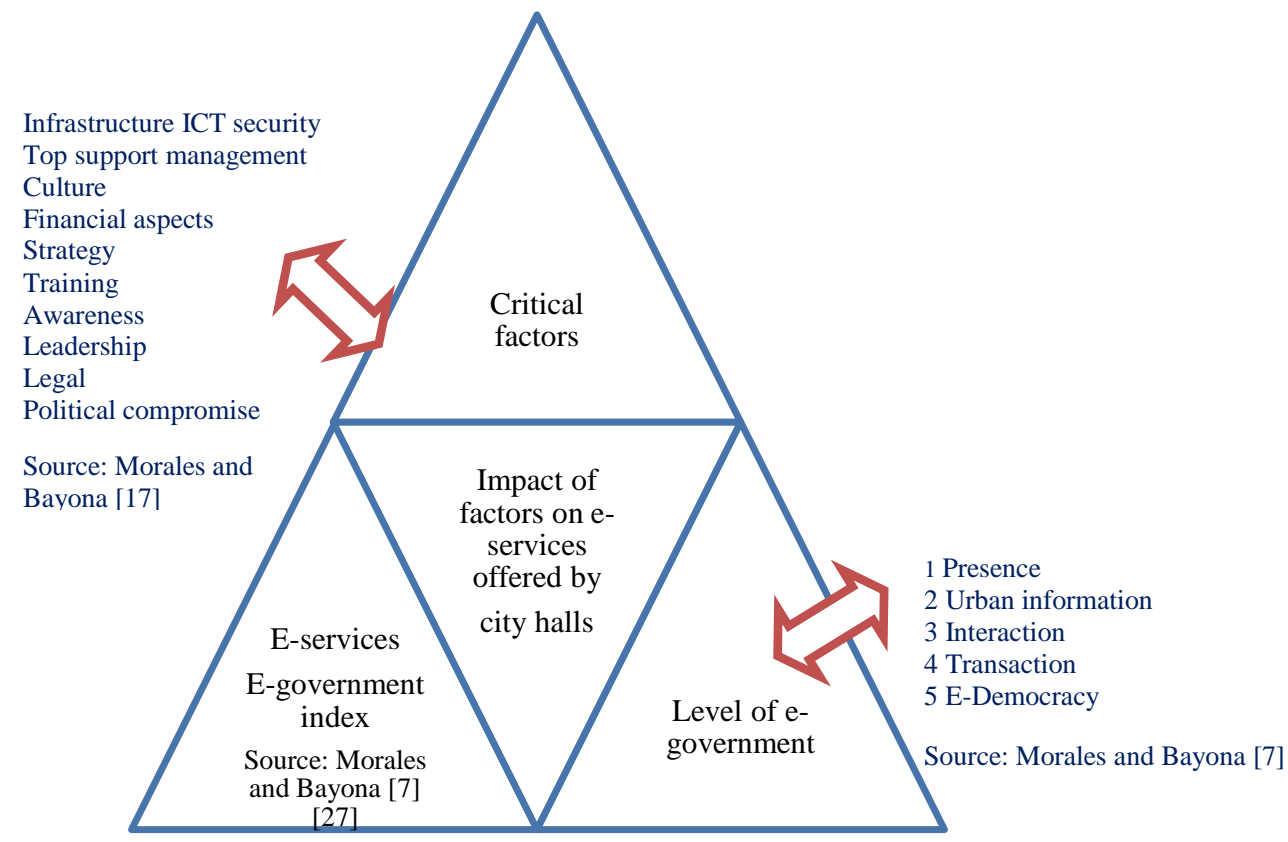

Figure 2. Critical factors, e-services and level of e-government

Among the most important aspects in the process of transforming organisations are qualified human resources with ICT knowledge and skills. Digital transformation is more associated with the acquisition and use of cutting-edge technology, however this is not enough to achieve the transformative impact. Experts attribute this failure to the lack of culture of leaders and decision makers [28].

Town halls must have access to specialised personnel for the management of e-services. Local governments, in particular, do not always have sufficient resources to implement new online services. Town halls thus must establish the infrastructure to support the implementation of new services and move from the level of only offering information to providing online services.

In many cases, town halls have a basic ICT infrastructure for administrative procedures and for information management and dissemination. With only a basic infrastructure, however, providing online services is a challenge. Therefore, town halls must update their existing basic infrastructures to provide efficient and effective e-services. Importantly, these updates must be carried out within the framework of good ICT governance.

Security and trust have been mentioned among the concerns associated with the adoption of e-services. Because e-governance entails not just the implementation of online services, moreover, but also the improvement of processes related to those services, leadership is another crucial factor.

While ICTs are recognised as powerful tools for improving citizen participation and building trust, few web portals exhibit evidence of citizen-centred initiatives, and this is true even beyond the town halls under study. Thus, the digital transformation leader must develop the skills and knowledge to improve egovernment indicators via a citizen-centred vision.

Despite its contributions, our study involves limitations, which can be addressed by future research. For example, in evaluating the e-services municipalities offered through their municipal portals, we employed dichotomous values of 1 and 0 . The value ' 1 ' was assigned if the e-service was implemented and ' 0 ' if it was not. However, these dichotomous values are too simplistic to provide a comprehensive evaluation of e-services.

At the presence level, for example, the search eservice can be simple or advanced, and each possibility should thus have different weights. Similarly, at the urban information level, the library e-service might only offer information from the library via the web portal or it might allow virtual loans to citizens. At the level of interaction, municipalities must not only disseminate email eservices on their websites but also offer timely responses, and similar criteria should apply to telephone e-services. At the transaction level, evaluating online services must take into account all of the services offered by the municipality as well as 
the services that are actually offered online. In the case of e-democracy, efforts to assess the surveys eservice should not only ask whether the municipality conducts surveys but also how these results are used to improve the e-services the municipality offers.

We thus propose that future works calculate the egovernment index using non-dichotomous values. Likewise, we urge more in-depth qualitative studies to explore the reasons limiting municipalities' offerings of e-services. Finally, citizens' underuse of implemented e-services is another aspect that must be analysed using technology adoption models.

\section{Conclusions}

This research contributes to the e-government topic and identifies the critical factors impacting e-services diffusion. Recognising that local governments' proximity to citizens elevates their importance, this study focuses on e-government at the municipal level. In this way, this research departs from and extends the extant literature, which has tended to focus on e-government at the national level. For local governments, a starting point is to evaluate e-services based on town hall web portals. This case study analysed the level of e-government achieved by 10 town halls and highlighted the factors critical for improving the current e-government indices and the provision of online services. Because most of the town halls analysed remain in the early stages of egovernment development, their web portals are primarily oriented towards the dissemination of information or interaction. This situation forces citizens to carry out face-to-face procedures. Then, it is necessary that city halls develop strategies in order to complete the e-services and achieve the transaction and e-democracy level. At all levels, a e-government initiative is conditioned by a set of critical factors, and decision-makers and ICT staff must take these factors into account to advance towards egovernment at the levels of interaction, transaction and e-democracy. Future work must determine the critical factors that influence on the levels of egovernment development using qualitative research.

\section{References:}

[1] Osei-Kojo, A. E-government and public service quality in Ghana. Journal of Public Affairs, Vol. 16, No. 1, pp. 1-2, 2016.

[2] Rodrigues, S. Local e-government models: a comparative and critical overview. The Matopolska School of Economics in Tarnów Research Papers Collection, Vol. 40 No. 4, pp. 95-114, 2018.

[3] Verkijika, S., De Wet, L. E-government adoption in sub-Saharan Africa. Electronic
Commerce Research and Applications, Vol. 30, pp. 83-93, 2018.

[4] Glyptis, L., Christofi, M., Vrontis, D., Del Giudice, M., Dimitriou, S., Michael, P. Egovernment implementation challenges in small countries: the project manager's perspective. Technological Forecasting and Social Change, Vol. 152, pp. 1-16, 2020.

[5] United Nations. United Nations E-Government Survey 2020: Digital Government in the Decade of Action for Sustainable Development, United Nations, New York, 2020.

[6] Auffret, J. Rural and municipal e-government initiatives in developing countries: best practices and a framework for success. Journal of E-Governance, Vol. 33, pp. 139-1431, 2010.

[7] Morales, V., Bayona, S. Modelo conceptual de desarrollo de e-gobierno para las municipalidades. Revista Ibérica de Sistemas e Tecnologias de Informação (RISTI), Vol. E28, pp. 600-614, 2020.

[8] Fajar, S., Amalia, A. The critical success factors model for e-government implementation in Indonesia, in 2017 5th International Conference on Information and Communication Technology (ICoIC7), Melaka, Malaysia, pp. 1-5, 2017.

[9] Müller, S., Skau, S. Success factors influencing implementation of e-government at different stages of maturity: a literature review. International Journal of Electronic Governance, Vol. 7, No. 2, pp. 136-170, 2015.

[10] Mensah, R., Cater- Steel, A., Toleman, M. Factors affecting e- government adoption in Liberia: a practitioner perspective. The Electronic Journal of Information Systems in Developing Countries, Vol. 12161, pp. 1-15, 2020.

[11] Morales, V., Bayona, S. Modelo conceptual de factores y su influencia en los niveles de desarrollo del e-gobierno municipal. Revista Ibérica de Sistemas e Tecnologias de Informação (RISTI), Vol. E28, pp. 28-41, 2020.

[12] Naser, A., Ramírez-Alujas, A., Rosales, D. Desde el gobierno abierto al estado abierto en América Latina y el Caribe, Cepal, Naciones Unidas, Santiago, 2017.

[13] United Nations. United Nations E-Gobierno Survey 2016 http://workspace.unpan.org/sites/Internet/Docu ments/UNPAN97453.pdf

[14] Organization for Economic Co-operation and Development. The E-Government Imperative, OECD Press. France, 2003.

[15] Bayona, S., Morales, V. E-government development models for municipalities. Journal 
of Computational Methods in Sciences and Engineering, Vol. 17, pp. 47-59, 2017.

[16] Joseph, B. Determining factors influencing egovernment development in the developing world: a case study of Zambia. Journal of EGovernment Studies and Best Practices, Vol. 2017, pp. 1-16, 2017.

[17] Morales, V., Bayona, S. Factores críticos de éxito en el desarrollo de e-gobierno: revisión sistemática de la literatura. Revista Ibérica de Sistemas e Tecnologias de Informação (RISTI), Vol. E23, pp. 233-247, 2019.

[18] El-Haddadeh, R., Al-Shafi, S., Weerakkody, V., Ali, M. E-government implementation challenges: a case study. Proceedings of the Sixteenth Americas Conference on Information Systems, 2010.

[19] Rodríguez, L., García, I., Gallego, I. Determining factors of e-government development: a worldwide national approach. International Public Management Journal, Vol. 14, No. 2, pp. 218-248, 2011.

[20] Rahman, S., Rashid, N., Yadlapalli, A., Yiqun, L. Determining factors of e-government implementation: a multi-criteria decisionmaking approach. In PACIS 2014 Proceedings, 302, 2014.

[21] Morales V., Bayona S., Morales, J. Categorización de factores críticos de éxito en el desarrollo de e-gobierno, Revista Iberica de Sistemas e Tecnologias de Informacao (RISTI), Vol. E31, pp. 590-602, 2020.

[22] Altameem, T., Zairi, M., Alshawi, S. Critical success factors of e-government: a proposed model for e-government implementation.
Proceedings of the IEEE Innovations in Information Technology Conference (IIT 2006), 19-21 November, Dubai, UAE, 2006.

[23] Lindgren, I., Jansson, G. Electronic services in the public sector: a conceptual framework. Government Information Quarterly, Vol. 30, No. 2, pp. 163-172, 2013.

[24] Jansson, G., Lindgren, I. Putting 'public' back into public e-services: a conceptual discussion. In Scholl H.J. et al. (Eds.), Electronic Government and Electronic Participation. Joint Proceedings of Ongoing Research and Projects of IFIP EGOV and IFIP ePart 2012. Trauner Verlag, 2012.

[25] Lindgren, I., Melin, U. Time to refuel the conceptual discussion on public eservices revisiting how e-services are manifested in practice. In International Conference on Electronic Government, pp. 92-101. Springer, 2017.

[26] Yin, R. Case Study Research Design and Methods (5th ed.). Thousand Oaks, CA, 2014.

[27] Bayona, S., Morales, V. Maturity model for local e-government: a case study. In Proceedings of the 8th International Conference on Computer Modeling and Simulation (ICCMS '17). Association for Computing Machinery, New York, NY, USA, pp. 78-83, 2017.

[28] Mugge, P., Abbu, H., Michaelis, T., Kwiatkowski, A., \& Gudergan, G. Patterns of Digitization: A Practical Guide to Digital Transformation. Research Technology Management, 63(2), 27-35, 2020.

\section{Creative Commons Attribution License 4.0 (Attribution 4.0 International, CC BY 4.0)}

This article is published under the terms of the Creative Commons Attribution License 4.0

https://creativecommons.org/licenses/by/4.0/deed.en_US 